\title{
めっき装置におけるトラブルとその対策
}

\author{
松下 哲 ${ }^{\mathrm{a}}$
}

a 松下技術士事務所 機械部門技術士 ( ₹ 354-0035＼cjkstart埼玉県富士見市ふじみ野西 2-1-1 アイムふじみ野 西 2-1201)

\section{Trouble and Solution of Plating Equipment}

\section{Testuo MATSUSHITA ${ }^{a}$}

${ }^{a}$ Professional Engineer of Mechanical Engineering, Matsuhita Consulting Engineering Office(Aimufujimino-W2-1201, 2-1-1, Fujiminonishi, Fujimi-shi, Saitama 345-0035)

Keywords : Carrier Type, IC Lead Frame, LED, PCB Through Hole Plating, Air Bubbling

\section{1. はじめに}

私は機械の技術者です。

機械の技術者がこの業界(めっき業界)で三十五年以上も仕 事ができたのは, めっき業界に機械技術者が異常に少なかっ たからです。仕事がらめっき工場のトラブルに立ち会う機会 が多く, その都度,「めっき現場の人たちももう少し機械の ことを知っていれば, ここまでトラブルを複雑にしなくても すんだのでは」と思います。

「めっき現場のトラブル」の $70 \%$ ～ $80 \%$ は，機械・装置· 人が原因でめっきトラブルになっていることがわかりました。 化学は, 消耗した薬品, 分析でバランスが崩れている薬品 を補充することで元に戻すことができると思います。電気制 御は, プログラムを変更しない限りプログラム通り動作する ことは不変です (センサなどの経時的に変化する部品もあり ますが)。機械は, 最初がベストで, 使えば必ず摩耗するので, 摩耗部品を交換しない限り元には戻りません。人は, 心, 技 術, 体調が日々変化していますから, いつも同じことができ るとは限りません。

このような条件から「めっき現場のトラブル」を見ると， どうもトラブルの原因は機械・装置・人が原因ではないかと 思うようになりました。不思議なことに機械・装置・人が原 因という見方をするようになってから，(思えばずいぶん昔 からそのように思っていたようです）「めっき現場のトラブ ル」を見る目が変わりました。

ここから，実際にめっき現場で発生したトラブルの現象・ 原因・対策を述べていきます。

\section{2. 機械・装置・人が原因のトラブル}

\section{1 引つ掛けジグからの製品落下}

【現象】キャリア式めっき装置で，製品をスプリングでは さむ形式の引っ掛けジグを使い板状の部品の銅めっきをして いましたが, めっき槽に製品が落下し, 溶けてめっき液の組 成のうち鉄分が異常に増えて, めっき不良を出しました。
現場では製品がジグから落下するという現象を解消するた め，ジグのスプリングを曲げグリップカを強くする対策をし ました。

当然スプリングを強くすればしばらくの間は製品の落下は なくなりましたが，また落下するようになりました。スプリ ングを曲げてグリップカは強くなりますが，限界があります。 また現象は解決できても原因がなくなったわけではありませ んから，また同じ製品落下トラブルが起こります。

【原因】現場の確認をすると,キャリアの動作がぎこちなく， スタートノストップ時にショックが大きくその都度吊り下げ たジグにショックが伝わり，製品落下の現象が出ていました。 機械的に見たらドライブチェインの伸びが原因でキャリアの 動作がぎこちなくなっているということを, 機械技術者なら 最初に疑います。この装置は天井走行式キャリア装置だった ので, 脚立で上りキャリアの駆動部を確認すると, 案の定, 走行チェインが弛んでいることがわかりました。駆動部には 必ずと言っていいほど, チェインの伸びを管理するため緊張 プーリーと言う部品があります(図 1)。図では, これを下方 に調整すればチェインのたるみは解消されます。

キャリア式めっき装置ではキャリアの走行, 昇降駆動は正 転／逆転の繰り返しですから, 駆動チェインは伸びやすいの で監視，管理は必要です。

【対策】原因がわかれば後は簡単です。工具が使える人な らば, 誰でもメンテナンスできます。しかし, この現場の場 合は工具が問題でした。チェインをピンと張るため, スパナ とモンキーと言う工具を持ってきたのですが，工具は錆びて 使うことができませんでした。私見ですが工具が錆びて使え ない状態では機械・装置のメンテナンスはできないので, こ のような現場では自動機を使う資格がないと考えています。 めっき現場では薬品を多く使用していますから, 工具は錆び る傾向にあるのですが, 一般的に工具はニッケルークロム めっきやハードクロムめっきが施されていますから, 薬品が ついても良く水洗いして乾かせば錆びはかなり防ぐことがで きます。また, 他の対策として, 駆動チェインを使わない構 


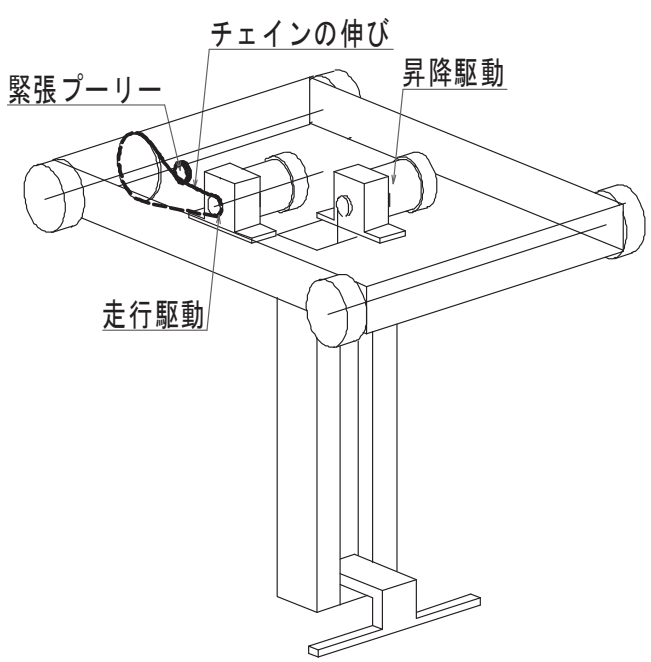

図 1 天井走行キャリアの模型図

造, ギア駆動や軸上減速機等にすることによりチェインの伸 びは気にすることはなくなります。

\section{2 キャリア停止位置異常}

【現象】最近では，キャリア式めっき装置でキャリアの位 置検出にエンコーダを採用することが多いですが， キャリア の位置をエンコーダに認識させるためラックギアを使います。 ラックギアとは, ギアと同じ歯型を直線にしたラック(レー ル上に配置します) とギアの組み合わせでキャリアが移動 (走 行)する時, ラックの歯で平ギアを介してエンコーダが回転し, 回転パルスをカウントしてキャリアが現在のポジションを認 識するシステムですが, 装置の停止位置がずれるという現象 が出ました。停止位置がずれると，ジグの昇降時，装置に干 涉します。現場では位置がずれると言う現象を解消するため, キャリア運行プログラムの停止位置を設定する数值を変更し たのです。位置ずれの現象は数值の変更で解消したのですが, その後も頻繁に起こるようになりました。

【原因】キャリアレールの上面に異物が付着しキャリアが 上下に弾み, タイミングが悪いとラックとギアのかみ合いが はずれ，エンコーダの回転パルスが変わります。原因はもち ろんレール上の異物です。天井走行キャリアの場合，キャリ ア走行用レールはかなり高い位置にあるので, 装置の点検・ 管理の目が届きにくい場所です。さらに埃やごみ(工場建屋 金属梁の錆び落下)がたまりやすく, キャリアの車輪でレー ル上の圧接された状態でした。

【対策】対策は $5 \mathrm{~S}$ の徹底しかありません。工場建屋梁の 錆びも，定期的に塗装補修すれば防ぐことができます。天井 梁の塗装はがれなどは目視でわかりますが，レール上の異物 は点検をしなければなりません。点検・管理の徹底をしてく ださい。このトラブルは人が原因のトラブルといえるでしょ う。

\section{3 めっき面のシミ その 1}

【現象】ICリードフレームのめっき装置で, めっき後に最 終水洗一乾燥工程がありますが, 乾燥後にめっき面にシミ (ウォーターマーク)が出ました。現場では乾燥前の水洗の水 質が悪いと考え水洗の段数を増やしましたが, 一向にシミが なくなることはありませんでした。最終的には 5 段もの水洗
をしていました。

【原因】 5 段の水洗であれば十分な水洗で，乾燥直前の最 終水洗工程の水質は相当きれいなものでした。乾燥前の水洗 工程出口(乾燥入り口)には, 水切りエアーブローや絞りロー ラなどで水洗工程の水滴を極力少なくしていますが, 完全に 取り除くことはできません。めっき面には細かい水滴が残り ます。

この水滴を乾燥工程で完全に蒸発すればよいのですが，乾 燥工程のエアーに問題がありました。乾燥工程では熱量節約 のため $1 / 3$ 程度の新気を取り入れ， $2 / 3$ は熱風循環をす る構造になっていました(熱量節約のためエアー全量を循環 すると, 循環エアーの蒸気が飽和状態になり, 乾燥できなく なることがあります)。

【対策】この $1 / 3$ の新気の取り入れ口は工場の空気を取 り入れており，工場空気の埃等を製品に吹きかけていること が原因であると考え, 乾燥エアーの循環系にフィル夕を配置 したところ，シミは著しく軽減できました。現在では乾燥工 程のエアー循環系にヘパフィル夕を配置することが多くなり ました。

\section{4 めっき面のシミ その 2}

【現象】ICリードフレームの銀めっき工場の一部のエリア にめっき後の製品置き場があり, 製品置き場のめっき表面に シミが発生しました。

【原因】製品置き場の最上部の製品めっき面にシミが発生 したが，原因がつかめず相談にきました。シミを分析すると ナトリウムが検出されたのですが, 製品置き場の周辺には, ナトリウムはありません。なんでナトリウムのシミができる のかわからなかったのですが，めっき工場でナトリウムと いったら，脱脂工程にはナトリウム系薬品を使用しています。 現場を観察すると, 工場の空調の風がめっき装置の脱脂側か ら製品置き場側に流れていることがわかりました。ICのリー ドフレームのめっき装置は常時薬品を循環する構造ですから, 薬品が滝のように流れています。滝の周辺では薬品のミスト が発生し, 空調の流れにそって工場内を飛散, 浮遊し製品置 き場まで流れていることがわかりました。このミストの飛散 が原因と判断しました。

【対策】空調の流れを変えるため, 天井からビニールシー トを吊り，空気の流れを変えたことでナトリウムのシミはな くなりました。また, めっき装置からの薬品ミスト飛散を少 なくするため装置の排気系を確認したところ, 排気ダクトの 中にミストが入りミストが結晶化してダクト内に蓄積してお り，排気風量が不足していました。

\section{5 めっき面への異物付着 その 1}

【現象】LEDの全面銀めっき装置で，めっき完成後の製品 をチェック(出荷検査)するとめっき面に異物が付着していま した。もちろん，めっき不良のうちの異物付着ですから検査 では NGです。

【原因】プレス工程で製品に極めて小さなバリが多くあり, めっき工程でバリの極小先端に極小めっきが析出し, 液流に よってバリ先端から落ちてめっき処理槽内に浮遊します。浮 遊物はフィルタで除去しますが, 図 2 のような管理槽循環式 フィルタ系になっていました。このフィルタ系はめっき装置 




図 2 管理槽循環式フィルタ



の停止中でも常時フィルタを稼動しろ過できるメリットはあ りますが，管理槽の中で液が滞留する部分ができ，浮遊物を 完全には除去できません。すなわち, 浮遊物のあるめっき液 を噴き上げることになります。これでは製品に異物を吹き付 けることになります。

【対策】図 3, 噴き上げフィルタ式循環式のように, 噴き 上げポンプの処理槽側に (吐出側)にフィルタを配置し, ろ過 後の液を噴き上げる機構に変更しました。処理槽の中はろ過 後のめっき液になるので，異物 (銀微細粒) 付着というめっき トラブルが激減しました。

\section{6 めっき面への異物付着 その 2}

【現象】 PCB 銅スルーホールめっき装置で, 平面部に異物 付着(めっき面にザラっとした感触があり, 光沢が損なわれ ていた)があり，分析すると $\mathrm{Fe}$ が検出された。

【原因】キャリア式めっき装置で，キャリアの走行用駆動 モーターの位置, カウンターシャフトの錆び (図 4)が原因で した。

写真でわかるように走行駆動モーターがキャリアの中央に 配置されており，モーターにはカーボンブラシがあり摩耗し ます。摩耗で削れた微粉は空気中に浮遊し, めっき槽に落ち ることがあります。また駆動モーターから両輪を回転させる ためのシャフト (カウンターシャフト)に指で察ると, 指に茶 色く着くような錆びがありました。キャリアは装置の上を走

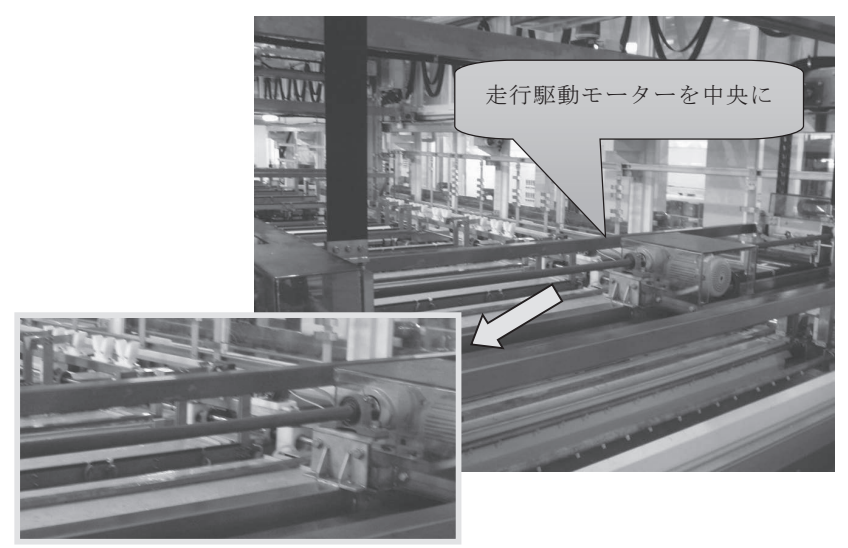



図３噴き上げ循環式フィルタ
行するので, モーターからの微粉, シャフトからの微粉が薬 品槽に落ち, 異物付着が発生します。設計時の材料選定不良 と検討不足が原因と考えられます。

【対策】モーターには全面を覆うカバーを付け, シャフト はステンレスに交換しました。モーターカバーはモーターの 過熱を防ぐため空気口を設けました。

\section{7 膜厚のバラツキ}

【現象】 PCB 全面金めっき装置でキャリアバーに吊るした $\mathrm{PCB}$ (幅 $50 \mathrm{~cm} \times 4$ 枚×高 $60 \mathrm{~cm}$ ) の幅方向に膜厚のバラッキ が $200 \%$ まで大きくなり, 現場の確認と dataの確認をすると, 特定のキャリアバーで発生していることがわかりました。

【原因】キャリアバーを装置内で詳細に確認したところ, 図 5 のようにキャリアバーのレスト部分が変形していて, キャリアバー受け $(\mathrm{V}$ 受け)との平行が出ていませんでした。 通常キャリアバーレストと V 受けとは並行に勘合し，通電 はレストの凸面と V 受けの凹面が全面で接触するのですが, 変形のため点接触になり正常な通電はできません。このため キャリアバーレストからの左右電流值バランスが悪く膜厚の バラツキが発生しました。

【対策】対策は，もちろんキャリアバーの矯正です。V受 けとキャリアバーレストとの接触が，面接触になるよう平行 にしました。ここでは接点(接触面)の洗浄も同時に行い，通 電が左右均一になるようにしました。直流配線の接続部の腐 食も通電の抵抗になるので同時にメンテナンスをしました。

キャリアバーの取り扱いに注意し，期間を設定し，定期的

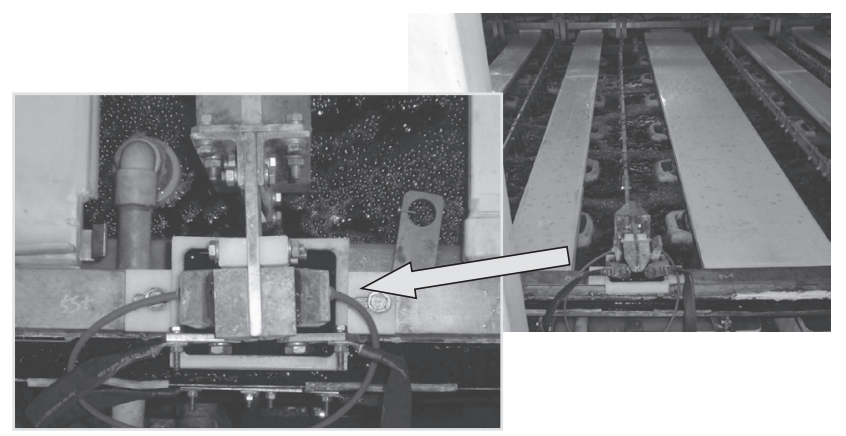


にキャリアバーの変形, 通電部面の状態をチェックすること を徹底しました。

\section{8 水洗槽内で FPCB はずれ}

【現象】 FPCB 硫酸銅めっき装置の水洗槽で FPCB がクリッ プ式ジグからはずれ，そのまま処理が進んだため，めっき不 良，変形になりました。

【原因】装置を詳細に確認して行くと, 酸活性後の水洗槽 のエアーバブリングの左右のエアー量が著しく異なっている ことがわかりました（図6）。エアーバブリングはリジット基 板のスルーホールめっきの場合は, わざわざ左右のエアー量 に差をつけて界面液流速に差をつけホールの内の液流通を 図ったのですが，その装置の設定のまま FPBC の全面めっき をしたので, 左右の界面液流速の差で FPCB が流速の早い方 向にふくらみ, 㮼られてクリップが一箇所はずれ変形し, めっ き不良になりました。はずれることがなくても，めっき工程 でもエアーバブリングをしているので, 左右の極間距離に差 ができてめっき厚のバラツキになります。

【対策】当然のことですが左右のエアー量を調整し，液流 速をほぼ同一にすることで解決しました。この場合左右のエ アー量調整用に別々にバルブがついていたので調整でできた ので助かりました。

\section{9 めっき密着不良}

【現象】コネクタめっき装置でキャリア部(くし状のつな がっている部分)の密着不良が発生しました。

【原因】めっき後の加熱テストでは密着不良はなかったの ですが，曲げ試験で曲げた部分がはがれ，密着不良が見つか りました。密着不良の下地部分に点状の酸化膜がありました。 酸化膜は面に発生することは多いですが，この例では点状で さらに分析すると, 一定距離に発生していました。密着不良

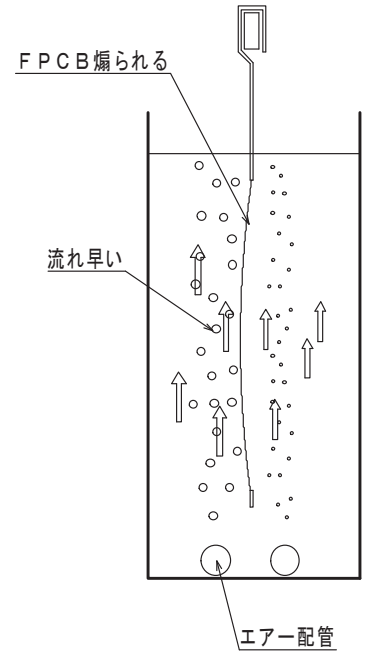

図 6 エアーバブリング
の原因はいろいろありますが，これは機械的なことが原因で した。

一定距離を測定すると，約 $180 \mathrm{~mm}$ のピッチでした。とい うことは回転体の $\phi 60 \mathrm{~mm}$ のものですから, すぐ給電ローラ またはガイドローラであることがわかります。コネクタの めつき装置には, 工程の中に 20 個程度の給電およびガイド ローラがあります。ローラ類を観察すると, Ni2 層目の給電 ローラにスパークの痕がありました。すなわち, 密着不良は $\mathrm{Ni} 2$ 層目の給電ローラでスパークが発生し, 微細な酸化膜が 生成，その上に $\mathrm{Ni} 3$ 層目をめっきしたことにより， Ni2 層目 と 3 層目の間で剥離が起こったのです。

【対策】スパークはどのようなときに発生するのか考えます。 スパークは，電流が流れている状態で強制的に接点を離す時 にスパークが出ます。常時電流が流れていれば，スパークは 発生しません。そこで対策としては, 給電ローラをめっき工 程の前後に配置し，常時通電ができるようにしました。また 給電ローラの給電面を研磨し，鏡面仕上げをしました。その 後スパークは発生しなくなり, スパークが原因の密着不良も なくなりました。

\section{3.おわりに}

今回は紙面の都合上, 九つの事例しかあげられませんでし たが，これは「めっき現場のトラブル」のほんの一部です。 事例のように機械・装置・人が原因の「めっき現場のトラブ ル」の現象だけをみて対応を間違えると原因を見つけること もできなくなります。“もう少し $5 \mathrm{~S}$ を徹底していれば”, “も う少し機械・装置のことを知っていれば”，と思うことが多 いのではないかと思います。「めっき現場のトラブル」はめっ き不良を生み, めっき不良は再加工費, 残業費など製造コス トアップになり会社の利益を損なうことになります。「めっ き現場のトラブル」の $70 \sim 80 \%$ は機械・装置・人のトラブ ルです。めっき現場には, 化学技術者, 品質管理技術者は多 いのですが，機械技術者，制御技術者は極端に少なく，また 育成する環境にないのが現状です。今後は機械技術者，制御 技術者を育成し, 機械・装置の「保守・点検 - 整備」を行え ば「めっき現場のトラブル」は減少し，会社の利益向上にな ることは目に見えています。

機会があればめっき工場における「保守・点検・整備」に ついてお話したいと思います。

謝辞

本稿の写真掲載にご協力いただいためっき工場に御礼申し 上げます。 